\title{
DIAGNOSTIC BIOMARKERS OF INFECTIOUS CANINE HEPATITIS IN EXPERIMENTALLY INFECTED PUPPIES
}

\author{
Khaled Kahilo ${ }^{1}$, Abdalla Moukhbtly², Samy Kasem ${ }^{3}$, \\ Mahmoud S. El-Neweshy ${ }^{4}$, and Naglaa Fouad ${ }^{1}$. \\ ${ }^{1}$ Department of Biochemistry, Faculty of Veterinary Medicine, \\ Kafrelsheikh University, Kafrelsheikh, Egypt \\ ${ }^{2}$ Department of Clinical Pathology, Faculty of Veterinary Medicine, \\ Kafrelsheikh University, Kafrelsheikh, Egypt \\ ${ }^{3}$ Department of Virology, Faculty of Veterinary Medicine, \\ Kafrelsheikh University, Kafrelsheikh, Egypt \\ ${ }^{4}$ Department of Clinical Pathology, Faculty of Veterinary Medicine, \\ Alexandria University, Egypt
}

\begin{abstract}
Infectious canine hepatitis (ICH) is a systemic disease of Canidae and Ursidae caused by canine adenovirus type $1(C A V-1)$ produces acute necrohemorrhagic hepatitis. The aim of the present study was to throw the light on the humoral and molecular diagnosis by polymerase chain reaction (PCR) and biochemical changes that occur in puppies infected with infectious canine hepatitis virus. Liver functions. tests, hematological profile, in addition to histopathological changes were performed.
\end{abstract}

The study was carried out on fourteen native breed puppies of about three to four months old, apparently healthy, free from internal and external parasites. They were fed balanced diet and adequate water and housed under hygienic conditions in special isolated kennels. The animals were not vaccinated, and found to be free from canine 
hepatitis antibodies as screened by serum neutralization test. Puppies were divided into two groups, group 1, composed of 11 puppies were experimentally infected group with ICHV, and group 2, composed of 3 puppies were kept as non-infected control group.

The results showed that, CAV-1 was detected in eight infected puppies by PCR showing amplicon of $508 \mathrm{bp}$ sizes at the $1^{\text {st }}$ and $2^{\text {nd }}$ week post viral infection. The infected puppies showed an elevation of serum enzymes activities as ALT, AST, ALP and GGT throughout the experimental period, also serum total protein and serum albumin were decreased at the $3^{\text {rd }}$ and $4^{\text {th }}$ week post infection. Concerning hematological profile the infected puppies showed a decrease of $\mathrm{HB}$, $R B C s$, platelets and haematocrit throughout the experimental period leading to anemia. The infected puppies showed a decrease of the total leukocytic count throughout the experimental period whereas neutrophils count increased significantly at the $1^{\text {st }}$ week post viral infection then decline to the normal level at the $2^{\text {nd }}$ week and finally decreased below the normal upper limits at the $3^{\text {rd }}$ and $4^{\text {th }}$ weeks. The infected puppies showed a decrease of lymphocytes count at $1^{\text {st }}$ week post viral infection and then rapidly increased at the $3^{\text {rd }}$ and $4^{\text {th }}$ week post viral infection. Moreover, the mean values of monocytes and eosinophils count increased gradually throughout the experimental period.

It was clearly observed from the present study that, PCR procedure is faster, sensitive and easier as diagnostic biomarkers for ICH especially at the acute stage. Moreover, liver functions tests as well as hematological indices were the best diagnostic biomarkers in the chronic stage of ICH. 


\section{INTRODUCTION}

Infectious canine hepatitis is a systemic disease of Canidae and Ursidae caused by canine adenovirus type 1 (CAV-1), (Appel, 1987). It is classified as group I (dsDNA), family Adenoviridae, genus Mastadenovirus and species canine adenovirus-1 (carter and wise, 2006). Infectious canine hepatitis, involves the massive destruction of liver cells (hepatocytes), (Hoskins et al., 2000). It is one of the acute hepatitis which firstly described by Rubarth, (1947) as it is a viral disease of the liver which produces striking hepatic damage in dogs and which has the experimental advantage of being caused by a cultivatable adenovirus.

Viral hepatitis is widespread in the canine population and is a common cause of death. It causes serious and sometimes fatal disease of dogs which severely harms infected animals. (Wang et al., 2007). Owing to the partial antigenic cross reactivity of CAV-1 with human adenoviruses subsequent investigation showed that, it is not known to produce disease in man. (Kapsenberg et al., 1959).

In the same line, ICH has the potential to do a great damage to cells throughout the body, initial cellular injury of the liver, kidney and eye is associated with cytotoxic effect of virus which ends in respiratory and eye infections. The main route of infection is ingestion of urine, feces, or saliva of infected dogs, the primary mode of transmission is by direct contact with an infected dog. Contaminated runs, cages, boots can also serve as a source of transmission (Foster and Smith, 2007).

Initial infection occurs in the tonsillar crypts and Peyer's patches, followed by viremia which lasts for 4-8 days, and infection of endothelial cells in many tissues. (Green, 1998). It was shown that, clinical signs of $\mathrm{ICH}$ may range from anorexia and lethargy to ataxia, seizures, paralysis 
and death (Cabasso, 1981). All unvaccinated dogs of all ages are at risk and susceptible to $\mathrm{ICH}$; however, the disease is most prevalent in dogs less than one year of age (Muller et al., 2010). The incubation period of the virus is from four to nine days (Buxton and Fraser, 1977).

Higuchi, (1990) reported that, the spread of a disease organism through populations of domestic or wild animals can be monitored by PCR testing. In many cases, the appearance of new virulent sub-types can be detected and monitored. The sub-types of an organism that were responsible for earlier epidemics can also be determined by PCR analysis.

Hu et al., (2001) reported that, PCR procedure is faster and easier to perform than any of the other assays used for detecting canine adenovirus, making it applicable in the rapid confirmation of diagnosis and differentiation of the two types of canine adenoviruses. Pursuing this further, they make a study to develop a simple method of detecting CAV-1, after electrophoresis, under the amplification conditions, $508 \mathrm{bp}$ PCR products were observed for CAV-1. Liver functions test are some of the most commonly performed blood tests. These tests can assess liver functions or liver injury.

An initial step in detecting liver damage is a simple blood test to determine the presence of certain liver enzymes in the blood. Under normal circumstances, these enzymes rise within the cells of the liver. But when the liver is injured for any reason, these enzymes are spilled into the blood stream. (Sharp and Dohme, 2011). Through infectious canine hepatitis virus infection there is increased liver enzyme activities and abnormal liver function test results were the most consistent clinicopathologic changes (Crawford et al., 1985). 
ALT is an enzyme present in hepatocytes of liver cells, when a cell is damaged, it leaks this enzyme into the blood, where it is measured. ALT rises dramatically in acute liver damage, such as viral hepatitis. (Nyblom, 2004). AST is similar to ALT in that it is another enzyme associated with liver parenchymal cells. It is raised in acute liver damage, but is also present in red blood cells and cardiac and skeletal muscle and is therefore not specific to the liver. The ratio of AST to ALT is sometimes useful in differentiating between causes of liver damage. Elevated AST levels are not specific for liver damage, and AST has also been used as a cardiac marker (Nyblom, 2006). ALP is an enzyme in the cells lining the biliary ducts of the liver; its levels in plasma will rise with large bile duct obstruction, intrahepatic cholestasis or infiltrative disease of the liver (Mengel, 2005).

Albumin is synthesized only in the liver; it is secreted across the sinusoidal surface of the hepatocyte into plasma from the Golgi apparatus. Hypoalbuminemia is noted in various liver disorders. Furthermore, albumin levels are decreased in acute and chronic liver disease, such as cirrhosis. The half-life of albumin is 18-20 days. Albumin alone is not considered to be an especial marker of liver synthetic function. (Martin, 1961).

Dogs suffered from infectious canine hepatitis suffered from leukopenia, the hemostatic defect of $\mathrm{ICH}$ was characterized by thrombocytopenia, abnormal platelet function, and anemia. (Wigton et al., 1976). On histopathological examination, intranuclear inclusion bodies were visible in hepatocytes, in association with hepatocyte dissociation and necrosis. (Thompson et al., 2010). 


\section{MATERIALS AND METHODS}

\section{Animals:}

Fourteen native breed puppies of about 3-4 months old, apparently healthy, free from internal (using serum neutralization test according to Yasumura and Kawatika, (1963) and external parasites. They were fed balanced diet and adequate water and housed under hygienic conditions in special isolated kennels. The animals were not vaccinated and found to be free from canine hepatitis antibodies as screened by serum neutralization test. They were divided into two groups, group (1) composed of 11 puppies were experimentally infected with CAV-1 (from number 1 to 11) and group (2) composed of 3 puppies (from number 12 to 14) were kept as non- infected (control) group. The animals were injected with the live local strain of CAV-1 with dose of $1 \mathrm{ml}$ intranasal and $2 \mathrm{ml}$ intravenous (one dose).

\section{Virus:}

The local virulent strain of CAV-1 (Khodeir et al., 2003) was kindly provided by the Department of Pet animal Vaccine Research, Veterinary Serum and Vaccine Research Institute, Abbassia, Cairo. The virus titer was $10^{6}$ TCT D50/ml (50\% tissue culture infective dose) and used for experimental infection of puppies.

\section{Specimens:}

Two blood samples were taken from jugular vein from each experimental animal, weekly for five weeks (one week before infection and four weeks post infection). The first blood samples were collected in heparinized tube for DNA extraction and hematological investigations. 
The second blood samples were collected in centrifuge tube and left to coagulate and centrifuged at $3000 \mathrm{rpm}$ for $15 \mathrm{~min}$ to provide serum for biochemical analysis. Serum was separated immediately and stored at $20{ }^{\circ} \mathrm{C}$ until analysis.

Liver specimens were obtained from the liver of the dead puppies for histopathological examination.

\section{Molecular detection of canine adenovirus virus 1 using polymerase chain reaction:}

It was made according to Linne, (1992); Kasem et al., (2010), for virus DNA detection in blood of infected dogs; DNA was extracted with DNA purification kit (Fermentas international Inc.) DNA was detected by using primers for CAV-1 (HU et al., 2001), forward and reverse primers (Foreword: HA1-5'-CGCGCTGAACATTACTACCTTGTC-3' and Reverse: HA2-5'-CCTAGAGCACTTCGTGTCCGCTT-3') (Sigma). HA1 is complementary to the genomic L chain at positions 770 and 791 (the numbers refer to the sequences) (Linne, 1992) in CAV-1. HA2 is complementary to the genomic $\mathrm{R}$ chain at positions 1274 to 1253 in CAV-1.

PCR was carried out by using TaKaRa LA Taq with GC Buffer (TAKARA BIO INC, Japan). A volume of $50 \mu 1$ contained $25 \mu 1$ of $2 \mathrm{x}$ GC buffer I, $8 \mu$ l of dNTP mixture, $0.5 \mu$ l of TaKaRa LA Taq, $5 \mu$ of each primer, $4.5 \mu 1$ of distilled water and $2 \mu 1$ of DNA. The open reading frame of the E3 regions of CAV-1 was amplified by using HA1 and HA2 primers, and PCR was carried out for 30 cycles, each consisting of denaturation at $96^{\circ} \mathrm{C}$ for $30 \mathrm{~s}$, annealing at $58^{\circ} \mathrm{C}$ for $1 \mathrm{~min}$ and extension at $72{ }^{\circ} \mathrm{C}$ for $1 \mathrm{~min}$. A final extension time of $5 \mathrm{~min}$ at $72^{\circ} \mathrm{C}$ was added at 
the end of the last cycle. Then, $10 \mathrm{~m} 1$ of each reagent was loaded onto $1 \%$ agarose gel electrophoresis in TAE buffer $(40 \mathrm{mmol} / \mathrm{L}$ Tris-acetate, $1 \mathrm{mmol} / \mathrm{L}$ EDTA, $\mathrm{pH}$ 8.0). The gel was stained with ethidium bromide (20 $\mathrm{mg} / \mathrm{L}$ in water) and photographed according to (Sambrook and Russel, 2001).

\section{Biochemical analysis:}

Determination of ALT, AST and ALP activities were measured according to Berth et al., (2004) using kits of Eliech clinical system company. Determination of GGT activity was performed according to Szasz, 1969 using kits of Bio-diagnostic Company. Determination of serum total protein was determined according to Gornall et al., (1949) using kits of Eliech clinical system company. Determination of serum albumin were made according to Dournas et al., (1971) using kits of Spectrum Company.

\section{Hematological profile:}

The complete blood picture of puppies were determined according to Ruben, (2011).

\section{Histopathological findings:}

Liver tissue specimens were collected and fixed in $10 \%$ neutral buffered formalin solution. Histopathological examination was carried out according to Culling and Hynes, (1983).

\section{Statistical analysis:}

Statistical analysis was performed according to SAS, 2005 using analysis of variance test for ANOVA, student t-test for comparing between different groups and Correlation Coefficient test for determining the relation between the different studied variables. 


\section{RESULTS}

\section{Virulence of $\mathrm{CAV}-1$}

Initial clinical signs detected at the end of the $1^{\text {st }}$ week post viral infection in all infected puppies were fever, loss of weight, vomiting, depression, corneal eye opacity and loss of appetite. At the $2^{\text {nd }}$ week post viral infection, infected dogs suffered from increased rectal temperature to the upper limits $\left(40{ }^{\circ} \mathrm{C}\right)$ at the last week of the experiment. all infected dogs were severely depressed and vomiting were evident. At the $3^{\text {rd }}$ week post viral infection, additional signs of Corneal opacity (blue eye) were seen in one animal and the first death occurred (animal no 9), the second death occurred at the $4^{\text {th }}$ week post viral infection (animal no 4). During $12 \mathrm{hr}$ prior to death the animals suffered from subnormal temperature, dark tarry stools, completely refusing to eat and general weakness of the body and arteries.

\section{Polymerase chain reaction (PCR)}

PCR procedure showed a clear 508 bp band. All animals under experiment were subjected to serum neutralization test and PCR assay. The results showed that, all animals under experiment were free from CAV-1 (table 1 ). At the $1^{\text {st }}$ and $2^{\text {nd }}$ week post viral infection nearly all infected puppies showed positive results with PCR assay, giving amplicon size of $508 \mathrm{bp}$ in agarose gel electrophoresis. The size of PCR products clearly indicated that, these isolates belong to CAV-1, no amplification was observed in animals number 6 and 8 and non-infected negative control group (figure 1). In the $3^{\text {rd }}$ and $4^{\text {th }}$ week post viral infection all infected puppies showed negative results. 
Khaled Kahilo et., al.

Table (1): Results of PCR for sample collected from the inoculated animal:

\begin{tabular}{|c|c|c|c|c|c|c|c|c|c|c|c|c|c|c|}
\hline Inoculated Animals & 1 & 2 & 3 & 4 & 5 & 6 & 7 & 8 & 9 & 10 & 11 & 12 & 13 & 14 \\
\hline $1^{\text {st }}$ week B & - & - & - & - & - & - & - & - & - & - & - & - & - & - \\
\hline $1^{\text {st }}$ week $P$ & + & + & + & + & + & - & + & - & + & + & + & - & - & - \\
\hline $2^{\text {nd }}$ week $P$ & + & + & + & + & + & - & + & - & + & + & + & - & - & - \\
\hline $3^{\text {rd }}$ week $P$ & - & - & - & - & - & - & - & - & \# & - & - & - & - & - \\
\hline $4^{\text {th }}$ week $P$ & - & - & - & $\#$ & - & - & - & - & \# & - & - & - & - & - \\
\hline
\end{tabular}

+ Virus DNA was detected

- Virus DNA was not detected

\# Sudden death B (before infection), P (post infection)
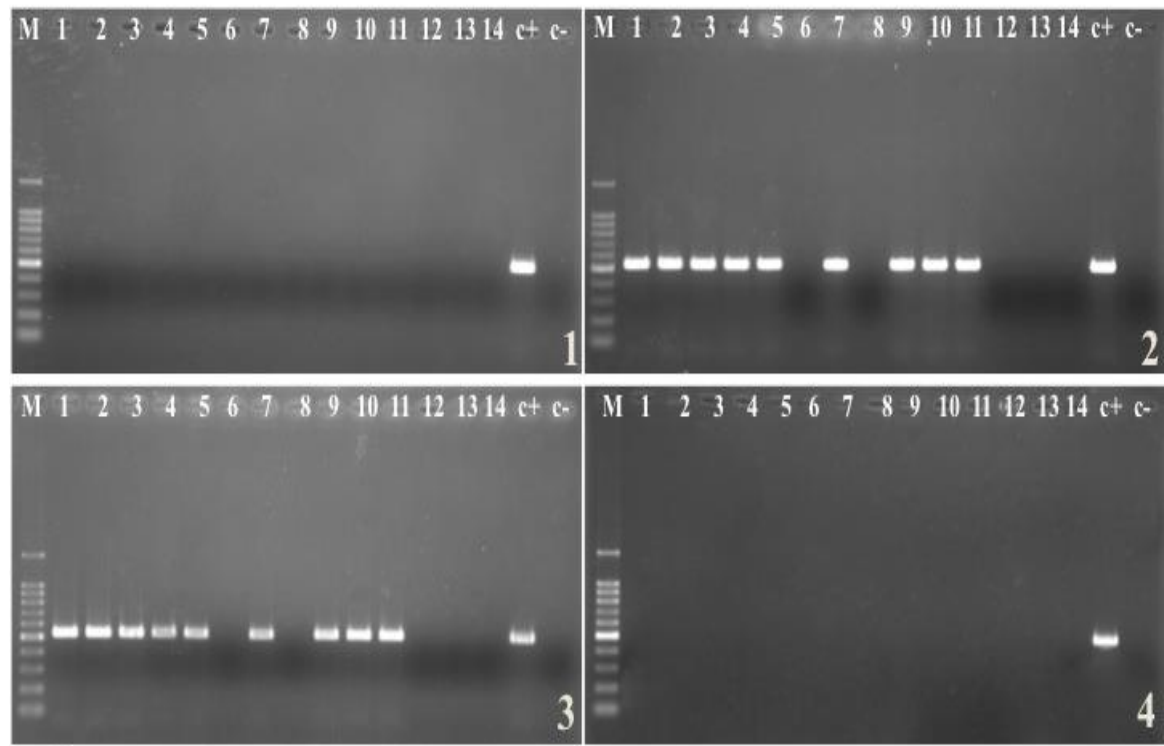

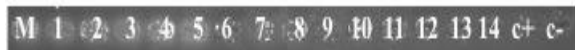

1: $1^{\text {st }}$ week $\quad 2: 2^{\text {nd }}$ week

$3: 3^{\text {rd }}$ week $\quad 4: 4^{\text {th }}$ week

5: $5^{\text {th }}$ week

M: 100bp ladder (Toyobo, Japan)

c+: ICH DNA (control Positive)

$5 \quad \mathrm{c}-:$ DW (control negative)

Fig. (1): PCR assay for detection of (CAV-1) form the extracted DNA from the blood of the inoculated puppies

$\overline{\overline{\text { Kafrelsheikh Vet. Med. J. Vol. } 10 \text { No. } 1 \text { (2012) }}}$ 


\section{Biochemical analysis}

Serum ALT, AST, ALP and GGT activities of puppies infected with $\mathrm{ICH}$ were significantly $(\mathrm{p}<0.01)$ elevated by the $1^{\text {st }}$ week post infection. ALT elevation was about 4 times than the upper normal level of control group at the $4^{\text {th }}$ week post viral infection. The elevation of AST activity was about 2 times than the upper normal level of control group at the $4^{\text {th }}$ week post viral infection. The increment of ALP activity was more than 2 times than the upper normal level of control group at the $4^{\text {th }}$ week post viral infection. The elevated GGT activity was more than 4 times the upper normal level of control group at the $4^{\text {th }}$ week post viral infection. (table 2 and figure2).

Table (2): Serum ALT, AST, ALP and GGT activities of puppies experimentally infected with infectious canine hepatitis virus in relation to blank control.

\begin{tabular}{|c|c|c|c|c|c|}
\hline Enzyme & Control & $1^{\text {st }}$ week & $2^{\text {nd }}$ week & $3^{\text {rd }}$ week & $4^{\text {th }}$ week \\
\hline \multirow{3}{*}{$\begin{array}{l}\text { ALT } \\
(\mathrm{U} / \mathrm{L})\end{array}$} & $\mathrm{D}$ & $\mathrm{C}$ & $\mathrm{C}$ & $\mathrm{B}$ & A \\
\hline & $50.04 \pm 2.47$ & $72.18 \pm 4.73$ & $71.91 \pm 12.19$ & $118.00 \pm 9.23$ & $159.78 \pm 15.43$ \\
\hline & $35-68$ & $49-98$ & $31-170$ & $83-170$ & $82-210$ \\
\hline \multirow{3}{*}{$\begin{array}{l}\text { AST } \\
(\mathrm{U} / \mathrm{L})\end{array}$} & $\mathrm{E}$ & $\mathrm{D}$ & $\mathrm{C}$ & B & A \\
\hline & $59.18 \pm 1.56$ & $65.55 \pm 3.99$ & $95.91 \pm 5.80$ & $112.00 \pm 8.10$ & $122.11 \pm 10.30$ \\
\hline & $49-71$ & $52-98$ & $62-128$ & $62-139$ & $69-151$ \\
\hline \multirow{3}{*}{$\begin{array}{l}\text { ALP } \\
(\mathrm{U} / \mathrm{L})\end{array}$} & $\mathrm{E}$ & $\mathrm{D}$ & $\mathrm{C}$ & $\mathrm{B}$ & A \\
\hline & $105.18 \pm 1.93$ & $215.00 \pm 16.83$ & $312.82 \pm 28.60$ & $401.60 \pm 47.18$ & $490.00 \pm 64.22$ \\
\hline & $96-118$ & $120-293$ & $115-397$ & $126-585$ & $139-610$ \\
\hline \multirow{3}{*}{$\begin{array}{l}\text { (GGT) } \\
(\mathrm{U} / \mathrm{L})\end{array}$} & $\mathrm{E}$ & $\mathrm{D}$ & $\mathrm{C}$ & $\mathrm{B}$ & A \\
\hline & $1.39 \pm 0.13$ & $2.09 \pm 0.28$ & $3.00 \pm 0.40$ & $4.10 \pm 0.64$ & $5.56 \pm 0.69$ \\
\hline & $1-2$ & $1-4$ & $1-6$ & $1-7$ & $1-8$ \\
\hline
\end{tabular}




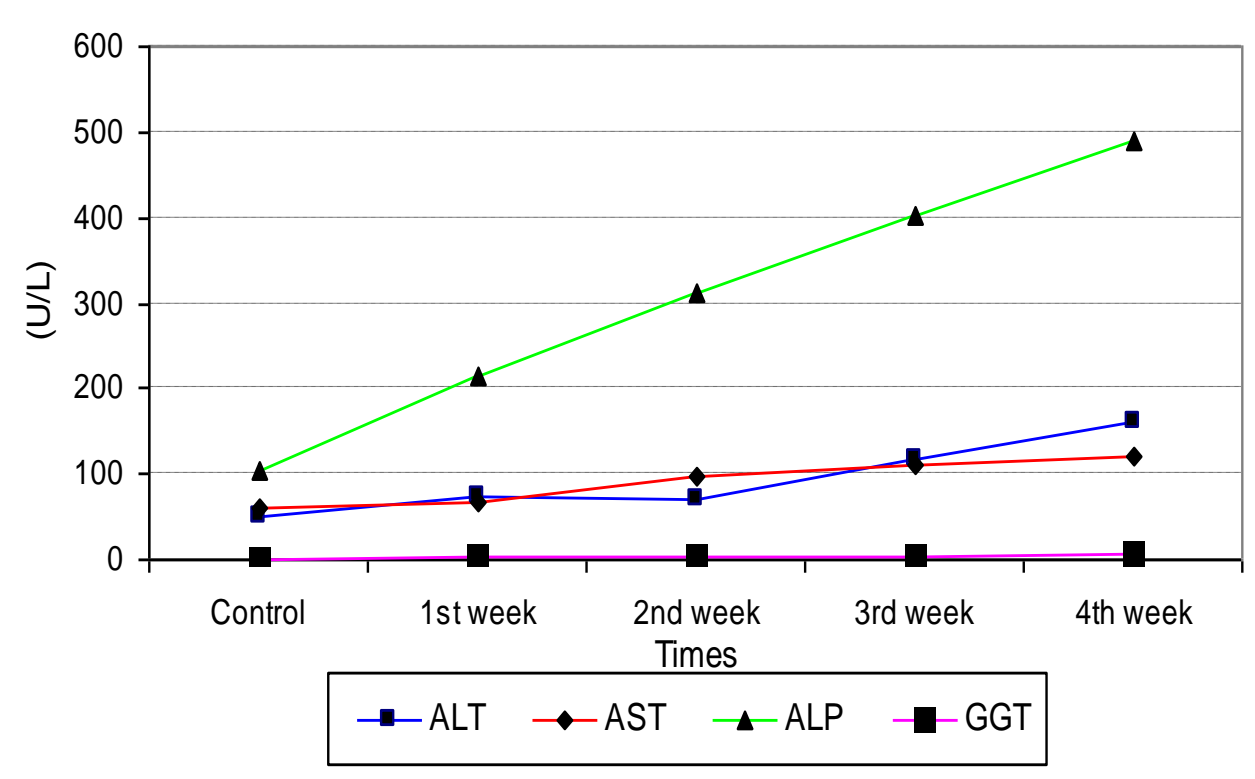

Fig. (2): Serum ALT, AST, ALP and GGT activities of puppies experimentally infected with infectious canine hepatitis virus in relation to blank control.

Serum total protein, albumin, globulins and $\mathrm{A} / \mathrm{G}$ ratio were significantly $(\mathrm{p}<0.01)$ decreased by the $2^{\text {nd }}$ week post viral infection. The level of increasing total protein at $1^{\text {st }}$ week post viral infection and then the decreasing was less than 3 times the lower normal level of control group at the $4^{\text {th }}$ week post viral infection. Albumin decreasing was less than 4 times the lower level of control group at the last period of the experiment. The decreasing of globulin level was less than 2 times the lower level of control group at the last period of the experiment. (Table 3 , figure 3 ). 
Diagnostic Biomarkers Of Infectious Canine Hepatitis In ...

Table (3): Serum total protein, Albumin, Globulin levels and Albumin/ Globulin ratio of puppies experimentally infected with infectious canine hepatitis virus in relation to blank control.

\begin{tabular}{|c|c|c|c|c|c|}
\hline Protein & Control & $1^{\text {st }}$ week & $2^{\text {nd }}$ week & $3^{\text {rd }}$ week & $4^{\text {th }}$ week \\
\hline Total & A & A & A & B & B \\
\hline Protein & $6.13 \pm 0.09$ & $6.48 \pm 0.23$ & $5.90 \pm 0.17$ & $4.93 \pm 0.21$ & $4.62 \pm 0.38$ \\
\hline$(\mathrm{g} / \mathrm{dl})$ & $5.59-6.71$ & $4.98-7.82$ & $4.71-6.63$ & $3.80-6.21$ & $2.65-6.45$ \\
\hline \multirow{3}{*}{$\begin{array}{l}\text { Albumin } \\
(\mathrm{g} / \mathrm{dl})\end{array}$} & $\mathrm{AB}$ & A & B & $\mathrm{C}$ & $\mathrm{D}$ \\
\hline & $3.03 \pm 0.05$ & $3.38 \pm 0.06$ & $2.90 \pm 0.17$ & $2.23 \pm 0.19$ & $1.59 \pm 0.27$ \\
\hline & $2.79-3.36$ & 3.02 & $2.02-4.02$ & $1.61-3.41$ & $0.86-3.31$ \\
\hline \multirow{3}{*}{$\begin{array}{l}\text { Globulin } \\
\text { (g/dl) }\end{array}$} & A & A & A & B & A \\
\hline & $3.10 \pm 0.09$ & $3.10 \pm 0.20$ & $3.00 \pm 0.27$ & $2.70 \pm 0.23$ & $3.03 \pm 0.21$ \\
\hline & $2.77-3.79$ & $1.62-3.93$ & $0.69-3.88$ & $1.09-3.39$ & $1.79-3.93$ \\
\hline \multirow{3}{*}{$\begin{array}{c}\text { Albumin/ } \\
\text { globulin (ratio) }\end{array}$} & A & $\mathrm{AB}$ & A & $\mathrm{AB}$ & B \\
\hline & $0.99 \pm 0.03$ & $1.15 \pm 0.10$ & $1.34 \pm 0.45$ & $0.97 \pm 0.20$ & $0.53 \pm 0.09$ \\
\hline & $0.77-1.21$ & $0.93-2.07$ & $0.57-5.83$ & $0.47-2.49$ & $0.30-1.18$ \\
\hline
\end{tabular}

Means within the same row of different letters are significantly differed at $\mathrm{P}<0.01$
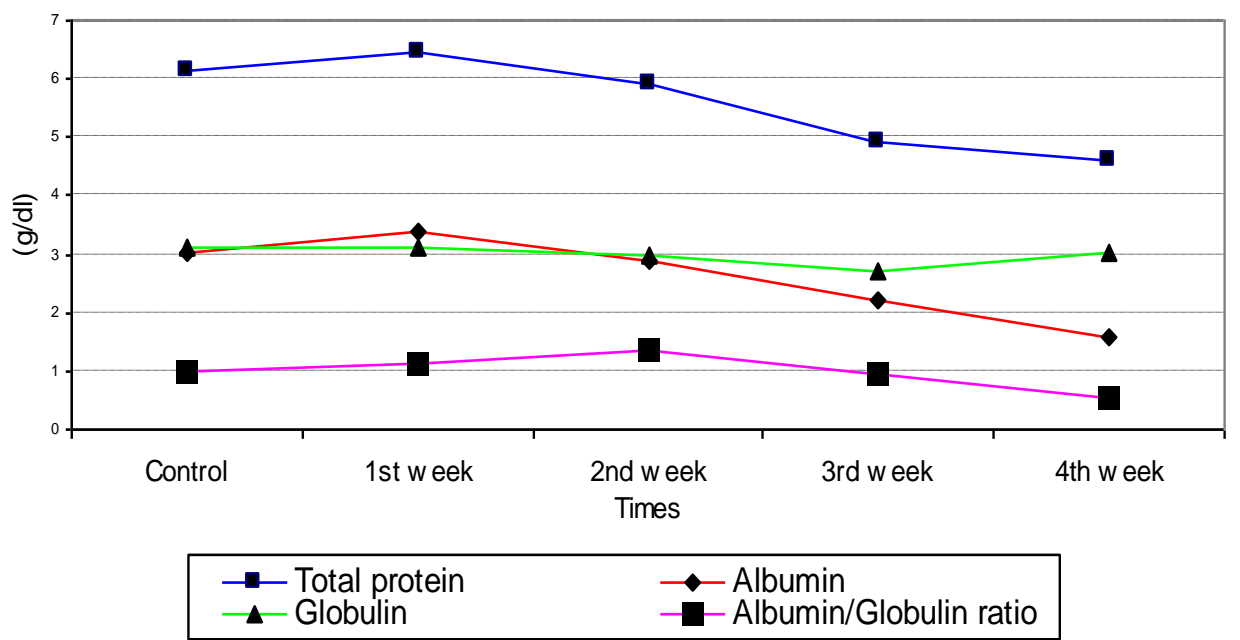

Fig. (3): Total protein, Albumin, Globulin and Albumin/globulin ratio levels of puppies experimentally infected with infectious canine hepatitis virus in relation to blank control. 


\section{Hematological analysis}

Complete blood count of puppies infected with $\mathrm{ICH}$ virus revealed that, there were a significant $(\mathrm{p}<0.01)$ decrease in the mean values of $\mathrm{HB}, \mathrm{RBCs}$, platelets and haematocrit at the $1^{\text {st }}$ week post viral infection (table 4 and figure 4 ).

Table (4): Haemoglobin, RBCs, Blood platelets and Haematocrite levels of puppies experimentally infected with infectious canine hepatitis virus in relation to blank control.

\begin{tabular}{|c|c|c|c|c|c|}
\hline Parameter & Control & $1^{\text {st }}$ week & $2^{\text {nd }}$ week & $3^{\text {rd }}$ week & $4^{\text {th }}$ week \\
\hline $\begin{array}{c}\text { Haemoglobin } \\
\text { (g/dl) }\end{array}$ & $\begin{array}{c}\mathrm{A} \\
12.11 \pm 0.45 \\
9.50-15.20\end{array}$ & $\begin{array}{c}\mathrm{A} \\
10.97 \pm 0.43 \\
8.70-13.30 \\
\end{array}$ & $\begin{array}{c}\mathrm{A} \\
9.99 \pm 0.46 \\
8.10-12.60\end{array}$ & $\begin{array}{c}\mathrm{B} \\
9.00 \pm 0.60 \\
7-12.50\end{array}$ & $\begin{array}{c}\mathrm{B} \\
8.02 \pm 0.74 \\
6-12.30 \\
\end{array}$ \\
\hline $\begin{array}{c}\text { RBCs } \\
\text { (mill/cu.mm) }\end{array}$ & $\begin{array}{c}\mathrm{A} \\
3.91 \pm 0.14 \\
3.09-4.66 \\
\end{array}$ & $\begin{array}{c}\mathrm{B} \\
3.53 \pm 0.13 \\
2.84-4.22 \\
\end{array}$ & $\begin{array}{c}\mathrm{C} \\
3.24 \pm 0.14 \\
2.66-4 \\
\end{array}$ & $\begin{array}{c}\mathrm{D} \\
2.93 \pm 0.19 \\
2.32-4 \\
\end{array}$ & $\begin{array}{c}\mathrm{E} \\
2.63 \pm 0.23 \\
2.01-3.96 \\
\end{array}$ \\
\hline $\begin{array}{l}\text { Blood platelets } \\
(1 \mathrm{X} \mathrm{10} / \\
\text { cu.mm) }\end{array}$ & $\begin{array}{c}\mathrm{A} \\
5.2 \pm 5.7 \\
3 \mathrm{X} 10^{5}-9 \\
\mathrm{X} 10^{5}\end{array}$ & $\begin{array}{c}\mathrm{B} \\
3.4 \pm 4.3 \\
2 \times 10^{5}-6 \times 10^{5}\end{array}$ & $\begin{array}{c}\mathrm{C} \\
1.9 \pm 2.6 \\
1 \times 10^{5}-4 \times 10^{5}\end{array}$ & $\begin{array}{c}\mathrm{D} \\
1.7 \pm 4.8 \\
7 \times 10^{5}-5 \times 10^{5}\end{array}$ & $\begin{array}{c}\mathrm{E} \\
1.3+4.3 \\
0.4 \mathrm{X} 10^{5}-4 \mathrm{X} \\
10^{5}\end{array}$ \\
\hline $\begin{array}{c}\text { Haematocrite } \\
(\%)\end{array}$ & $\begin{array}{c}\mathrm{A} \\
36.35 \pm 1.35 \\
28.50-45.60\end{array}$ & $\begin{array}{c}\mathrm{B} \\
32.91 \pm 1.30 \\
26.10-39.90\end{array}$ & $\begin{array}{c}\mathrm{BC} \\
29.98 \pm 1.38 \\
24.30-37.80\end{array}$ & $\begin{array}{c}\mathrm{C} \\
27.00 \pm 1.81 \\
21-37.50\end{array}$ & $\begin{array}{c}\mathrm{C} \\
24.07 \pm 2.23 \\
18-36\end{array}$ \\
\hline
\end{tabular}

Means within the same row of different letters are significantly different at $\mathrm{P}<0.01$.

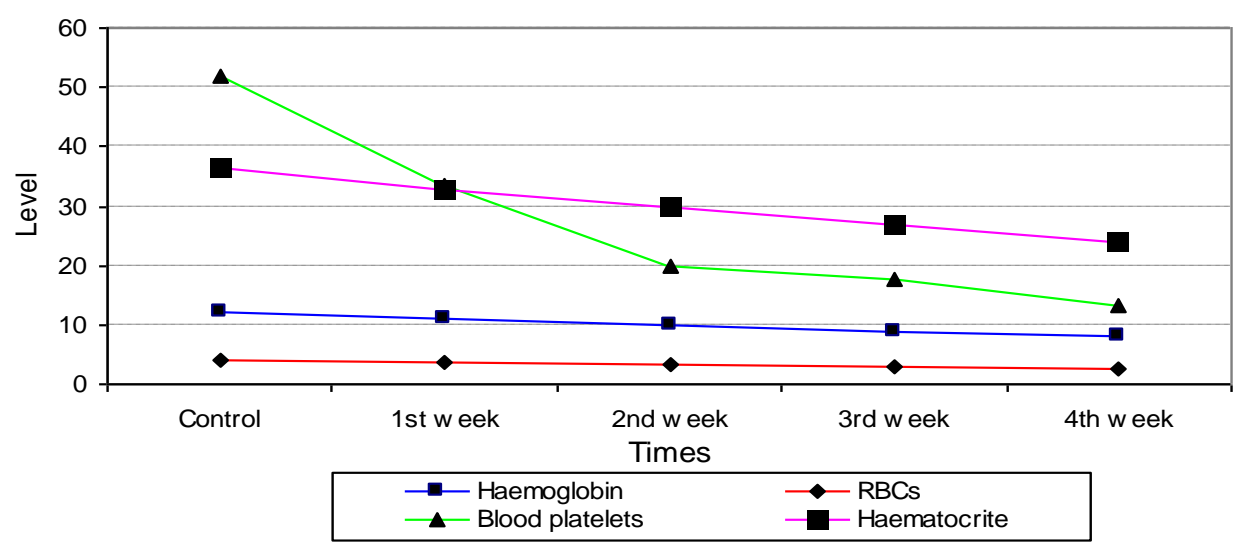

Fig. (4): Haemoglobin, RBCs, Blood platelets and Haematocrite levels of puppies experimentally infected $w$ ith infectious canine hepatitis virus in relation to blank control.

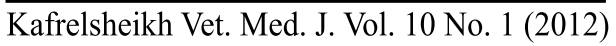


The total leukocytic count in blood of puppies infected with ICH virus decreased significantly during the experimental period whereas neutrophils count increased significantly at the $1^{\text {st }}$ week post viral infection then decline to the normal level at the $2^{\text {nd }}$ week and finally decreased below the normal upper limits at the $3^{\text {rd }}$ and $4^{\text {th }}$ weeks. The mean values of lymphocytes count decreased at the $1^{\text {st }}$ week post viral infection and then rapidly increased at the $3^{\text {rd }}$ and $4^{\text {th }}$ week post viral infection. Moreover, the mean values of monocytes and eosinophils count increased gradually throughout the experimental period (table 5, figure 5).

Table (5): WBCs, Neutrophils, Lymphocytes, Monocytes and Eosinophils levels of puppies experimentally infected with infectious canine hepatitis virus in relation to blank control.

\begin{tabular}{|c|c|c|c|c|c|}
\hline Parameter & Control & $1^{\text {st }}$ week & $2^{\text {nd }}$ week & $3^{\text {rd }}$ week & $4^{\text {th }}$ week \\
\hline $\begin{array}{l}\text { WBCs } \\
\left(1 \times 10^{3}\right)\end{array}$ & $\begin{array}{c}\mathrm{A} \\
9.36 \pm 0.77 \\
5-14\end{array}$ & $\begin{array}{c}\mathrm{A} \\
10.00 \pm 1.32 \\
5-19\end{array}$ & $\begin{array}{c}\text { B } \\
5.91 \pm 1.08 \\
3-14\end{array}$ & $\begin{array}{c}\mathrm{BC} \\
4.30 \pm 1.18 \\
1-12\end{array}$ & $\begin{array}{c}\mathrm{C} \\
3.89 \pm 1.37 \\
1-12\end{array}$ \\
\hline $\begin{array}{c}\text { Neutrophil } \\
(\%)\end{array}$ & $\begin{array}{c}\mathrm{B} \\
57.68 \pm 3.29 \\
21-68\end{array}$ & $\begin{array}{c}\mathrm{A} \\
70.36 \pm 1.02 \\
63-74\end{array}$ & $\begin{array}{c}\text { B } \\
58.91 \pm 2.44 \\
41-71\end{array}$ & $\begin{array}{c}\mathrm{C} \\
47.9 \pm 2.40 \\
41-62\end{array}$ & $\begin{array}{c}D \\
44.78 \pm 3.22 \\
37-64\end{array}$ \\
\hline Lymphocyte & $\begin{array}{c}\mathrm{C} \\
29.11 \pm 0.86 \\
22-34\end{array}$ & $\begin{array}{c}\mathrm{D} \\
18.09 \pm 1.38 \\
12-29\end{array}$ & $\begin{array}{c}\mathrm{C} \\
28.00 \pm 1.84 \\
21-41\end{array}$ & $\begin{array}{c}\text { B } \\
36.90 \pm 1.68 \\
26-43\end{array}$ & $\begin{array}{c}\text { A } \\
39.44 \pm 2.29 \\
27-46\end{array}$ \\
\hline $\begin{array}{c}\text { Monocyte } \\
(\%)\end{array}$ & $\begin{array}{c}\text { B } \\
3.61 \pm 0.38 \\
2-8\end{array}$ & $\begin{array}{c}\mathrm{A} \\
4.91 \pm 0.37 \\
3-7\end{array}$ & $\begin{array}{c}\text { A } \\
4.64 \pm 0.41 \\
3-7\end{array}$ & $\begin{array}{c}\mathrm{A} \\
4.70 \pm 0.37 \\
3-7\end{array}$ & $\begin{array}{c}\text { A } \\
4.67 \pm 0.41 \\
3-\end{array}$ \\
\hline $\begin{array}{c}\text { Eosinophil } \\
(\%)\end{array}$ & $\begin{array}{c}\text { B } \\
1.96 \pm 0.41 \\
1-7\end{array}$ & $\begin{array}{c}\text { A } \\
3.00 \pm 0.45 \\
1-6\end{array}$ & $\begin{array}{c}\mathrm{AB} \\
2.27 \pm 0.27 \\
1-4\end{array}$ & $\begin{array}{c}\text { A } \\
3.40 \pm 0.73 \\
1-9\end{array}$ & $\begin{array}{c}\mathrm{A} \\
3.11 \pm 0.65 \\
1-7\end{array}$ \\
\hline
\end{tabular}

Means within the same row of different litters are significantly differed at $\mathrm{P}<0.01$.

$\overline{\overline{\text { Kafrelsheikh Vet. Med. J. Vol. } 10 \text { No. } 1 \text { (2012) }}}$ 
Khaled Kahilo et., al.

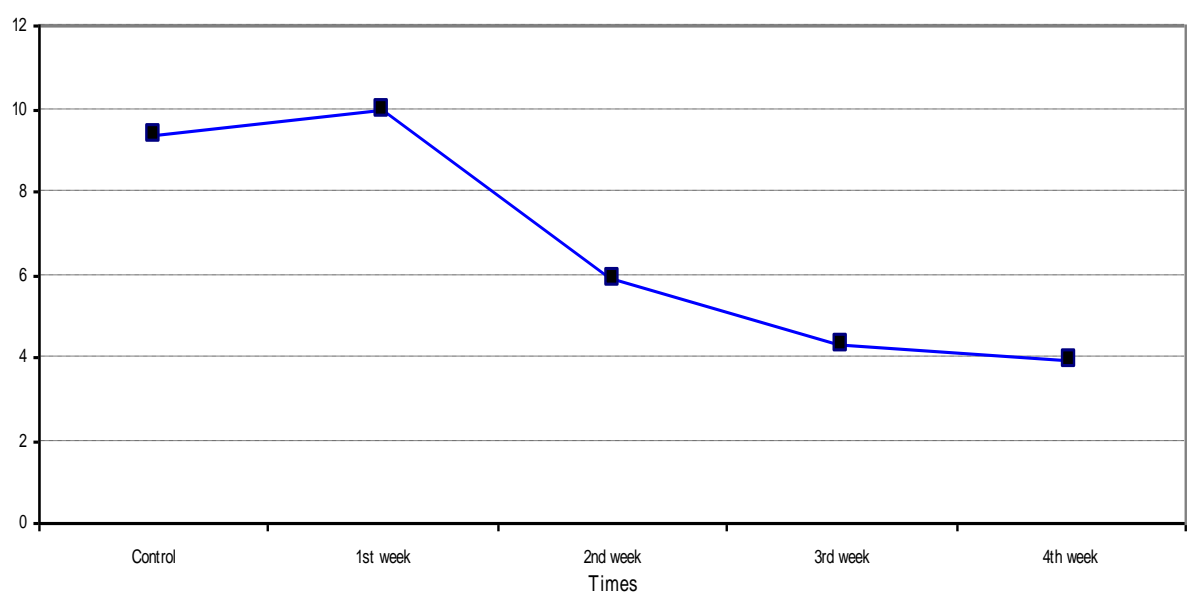

WBCs levels of puppies experimentally infected with infectious canine hepatitis virus in relation to blank control.

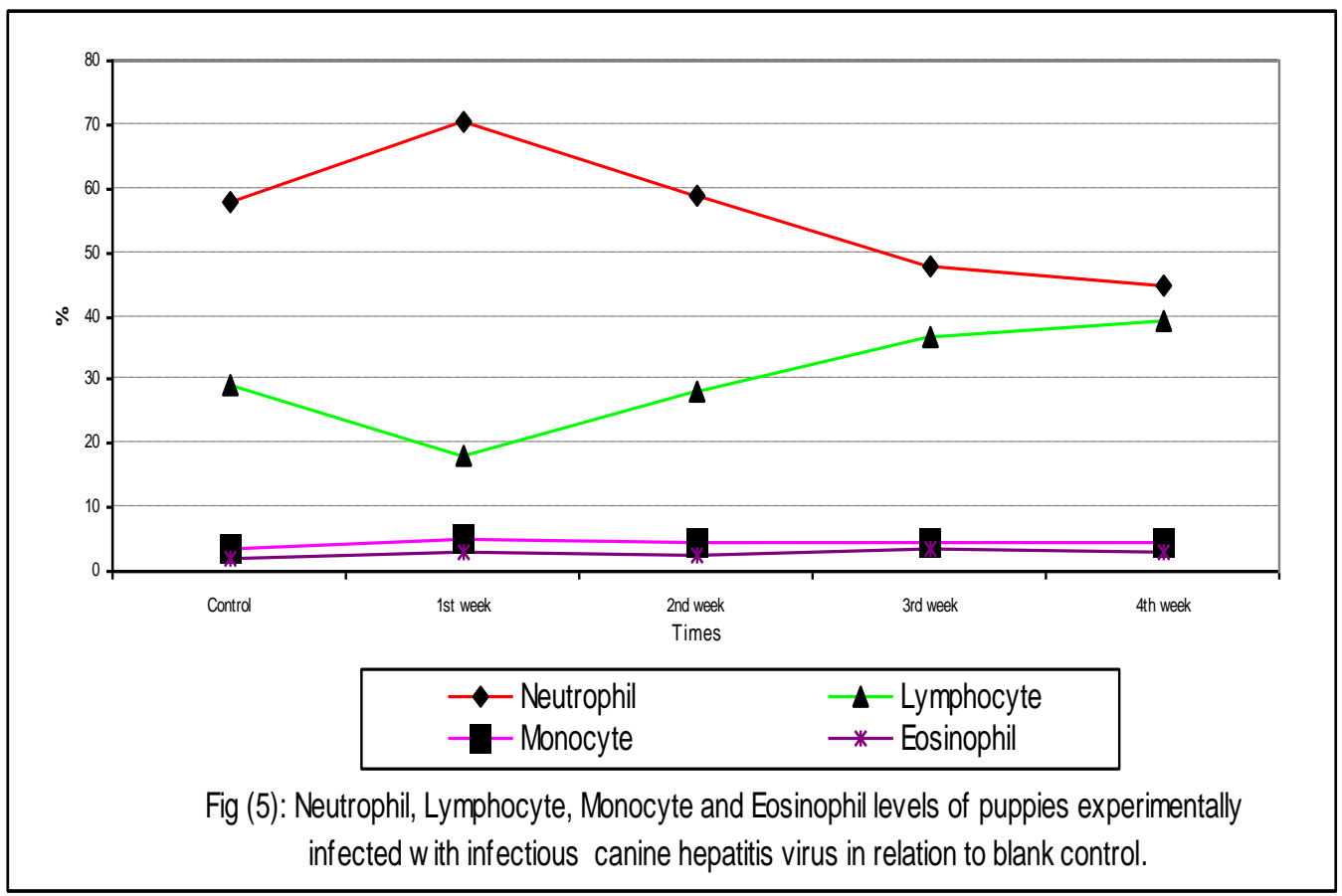

Kafrelsheikh Vet. Med. J. Vol. 10 No. 1 (2012) 


\section{Histopathological examination}

The liver of all infected puppies was mildly jaundiced and congested, with mild accentuation of the hepatic lobular pattern. The mesenteric and hepatic lymph nodes were mildly enlarged and congested. Histopathological examination of the liver from all infected puppies revealed generalized necrosis and dissociation of hepatocytes. Multifocal hepatic necrosis was also evident, intranuclear inclusion bodies typical of CAV-1 were visible in hepatocytes (Figure 6).

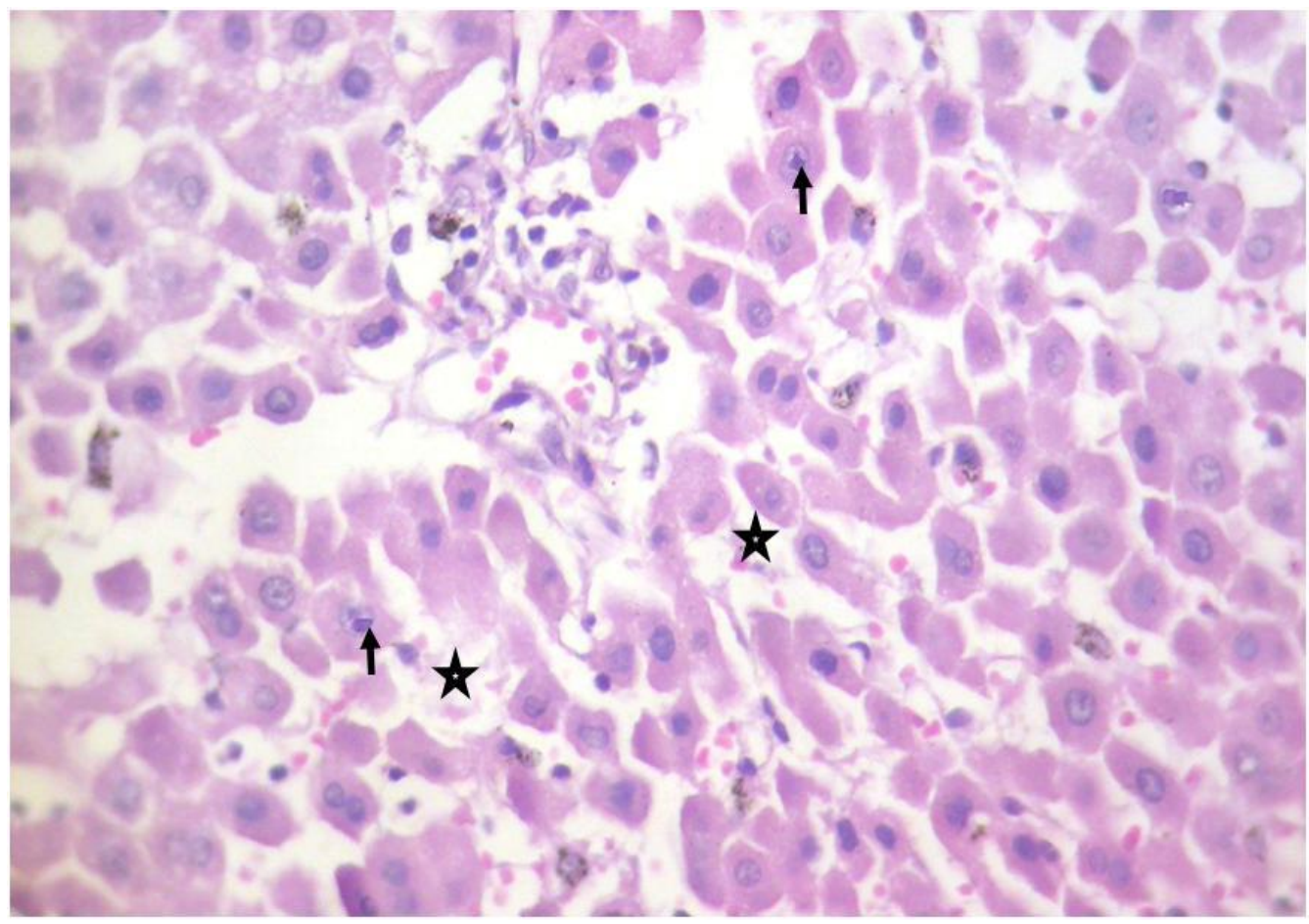

Fig. (6): Liver of puppies infected with ICH virus showing centrilobular hepatic necrosis (astrick) with basophilic intranuclear inclusion bodies within individual hepatocyts (arrows).H\&E(X250). 


\section{DISCUSSION}

Infectious canine hepatitis is an acute form of hepatitis. The clinical signs encountered in our present study were fever, weight loss, abdominal pain, vomiting, diarrhea and depression; these symptoms were previously described by Gerhold et al., (2007).

In the present study, the results concerning PCR procedure in the blood of dogs infected with infectious canine hepatitis virus indicated that, the appearance of the band was mainly clear at $3-9$ days post infection with ICH. This period is characterized by the feverish condition of the virus infection and the virus was highly active and facilitated the appearance of the bands of PCR. Our results agreed with those reported by Bexfield et al., (2011) they reported that, the PCR gave a good results for detection of ICH virus especially at the feverish stage of the virus affected the appearance of the bands, while after that the virus concentration decreased therefore the bands became not clear.

Therefore, our mentioned results which indicated the appearance of the clear bands at 3-9 days post infection could be attributed to the occurance of viremia which lasts for 4-8 days. Our present results agreed with those observed by Green, (1998) who reported that, natural oronasal exposure to infection directed the virus initially to be localized in the tonsils then migrated via blood stream through the thoracic duct. Rapid dissemination of the virus to other tissues and body secretions as saliva, urine and faces resulted in viremia, which lasts for 4-8 days. 
It was worthy noting that, CAV-1 detected by PCR assay gave positive amplicon size of $508 \mathrm{pb}$ in agarose gel electrophoresis and these results were exactly similar to that reported by $\mathbf{H u}$ et $\boldsymbol{a l . , ~ ( 2 0 0 1 ) ; ~ t h e y ~}$ observed that, Canine adenovirus type $1(\mathrm{CAV}-1)$ can be detected in the laboratory by using PCR electrophoresis, under the amplification conditions, $508 \mathrm{bp}$. Our experimental results confirmed that, although the virus can be found throughout the body, the liver was only the site of major injury. This fact was previously described by Rubarth, (1947).

The degenerative changes of the hepatocytes encountered in our experiment increased significantly serum ALT and AST activities. In the same respect, serum ALP and GGT activities were also significantly increased gradually following experimental viral infection. This increment could be attributed partly to the degenerative changes of hepatocytes as well as the involvement of bile canaliculi. Our results recorded about these findings agreed goes hand with hand with those reported by Pratelli et al., (2001) and Dkhil et al., (2010).

The significant decrease of the mean values of serum total protein as well as albumin could be attributed to the degenerative changes of the infected liver. Our present results were in complete agreement with those reported by Thornburg, (2000).

Abdelmagid et al., (2004) stated that, any elevation of liver enzymes indicates the higher liver damage and insufficiency of albumin synthesizing power of the liver as well as serum total proteins. While, the results of Moulton and Frazier, (1961) observed an increase in the protein level over $200 \%$ after infection. Our present results supported this fact only at the $1^{\text {st }}$ week post viral infection. 
Concerning the hematological profile of blood of infected puppies with ICH virus, the mean values of RBCs count, $\mathrm{Hb}$ level, haematocrit \% and platelets count were significantly $(\mathrm{p}<0.01)$ decreased compared to control group throughout the experimental period. This decrement could be attributed to the degenerative changes of the hemopioetic organs (liver, spleen, lung and bone marrow) responsible for synthesis of the above mentioned criteria. The obtained results were in complete agreement with those reported by Sharp and Dohme, (2011) they found that, infection with ICH is initially occurs in the tonsillar crypts and Peyer's patches, followed by viremia and infection of the endothelial cells lining of many tissues. They also added that liver, kidneys, spleen, and lungs are the main target organs.

Wigton et al., (1976) observed that, dogs infected with infectious canine hepatitis virus suffered from hemostatic defect characterized by abnormal platelets function and number.

The leucocytosis with neutrophilia, eosinophilia and monocytosis encountered in the present study at the $1^{\text {st }}$ week post infection might be attributed to stimulation of the bone marrow stem cells. Then leucopenia occurs, the obtained results were in agreement with those reported by Pratelli et al., (2001) they found that, during an outbreak of infectious canine hepatitis in dogs the dogs suffering from leucopoenia and they attributed these results to the degenerative changes that occur in different organs responsible for the leukocyte synthesis.

Moreover, the observed lymphocytosis, monocytosis and eosinophilia at the $4^{\text {th }}$ and $5^{\text {th }}$ week post viral infection could be attributed to the chronicity of the infection. Our present results goeshand

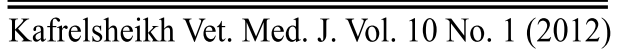


with hand with those reported by Thornburg, (1998) who observed that, liver tissue samples of dogs infected with infectious canine hepatitis virus exhibited an early changes manifested by inflammation and scar tissue deposition around the small hepatic vein branches. There was also apoptosis of scattered hepatocytes in zone 3 and the inflammation was characterized by increased macrophages, lymphocytes, and plasma cells.

Our histopathological study demonstrated that, there were a mild multifocal degeneration and necrosis of hepatocytes, centrilobular hepatocellular degeneration and necrosis. Additionally there were abasophilic intranuclear inclusion bodies in the hepatocytes. The previous findings could be attributed to the severe hepatocytic degeneration resulted from severe hepatitis which causes disturbances in biochemical parameters encountered in the present study. In general our results agreed well with the studies reported by Muller et al., (2010); Thompson et al., (2010) and Sharp and Dohme, (2011) they reported that, the infectious canine hepatitis is an acute infectious disease affecting dogs and causes severe degenerative changes in the liver, with consequent severe biochemical changes.

In conclusion the long duration of increased serum enzymes activities (ALT, AST, ALP and GGT) together with the relative disturbances in hematological profile probably reflect the degree of acute hepatic damage produced by ICH virus. In addition the use of PCR procedure for tracing the virus is of no value after the $2^{\text {nd }}$ week post viral infection. 


\section{REFERENCES}

- Abdelmagid, O.Y., Larson, L., Payne, L., Tubbs, A., Wasmoen, T. and Schultz, R., (2004). 'Evaluation of the efficacy and duration of immunity of a canine combination vaccine against virulent parvovirus, infectious canine hepatitis virus, and distemper virus experimental challenges'. Vet Ther, 5 (3):173-186.

- Appel, M.J., (1987). 'Canine Adenovirus Type 1 (Infectious Canine Hepatitis Virus)'. In: Appel, M.J. (Ed.), Virus Infections of Carnivores.Elsevier Science Publishers, Amsterdam, 29-43.

- Berth, M. and Delanghe, J., (2004). 'Protein precipitation as a possible important pitfall in the clinical chemistry analysis of blood samples containing monoclonal immunoglobulins: 2 case reports and a review of the literature'. Acta Clin Belg, 59 (5):263-273.

- Bexfield, N.H., Andres-Abdo, C., Scase, T.J., Constantino-Casas, F . and Watson, P.J., (2010). 'Chronic hepatitis in the English Springer spaniel: clinical presentation, histological description and outcome'. Vet Rec, 169 (16):415.

- Buxton, A. and Fraser, G., (1977). 'Adenoviruses. Animal microbiology'. Blackwell Scientific Publications, Oxford, UK, Vol.2. 725-735.

- Cabasso, V. J. (1981). 'Infectious canine hepatitis'. In Infectious diseases of wild mammals. ( $2^{\text {nd E.d.) }}$, J. W. Davis, L. K. Karstad and D. O.Trainer (eds.).Iowa State University Press, Ames, Iowa,191-195. 
- Carter, G.R.; Wise, D.J. (2006). 'Adenoviridae'. A Concise Review of Veterinary virology. From: http://www.ivis.org/advances/ Carter/ Part2Chap13/chapter.asp?LA=1.

- Crawford, M.A., Schall, W.D., Jensen, R.K. and Tasker, J.B., (1985). 'Chronic active hepatitis in 26 Doberman pinschers'. J.Am.Vet.Med. Assoc, 187 (12):1343-1350.

- Culling A.J. and Hynes, M.R., (1983). 'Processing of beta-endorphin in the dog intestine: regional specificity'. Proc West Pharmacol Soc 26: 95-99.

- Dkhil, M.A., Abdel-Baki, A.S., Wunderlich, F., Sies, H. and AlQuraishy, S., (2010). 'Anticoccidial and antiinflammatory activity of garlic in murine Eimeria papillata infections'. Vet Parasitol, 175 (12):66-72.

- Dournas, B.T., Watson, W.A., Biggs, H.G., (1971). 'Albumin standard and the measurement of serum albumin with bromocresol green'. Clin Chim Acta, 31:87-96.

- Foster, D., and Smith, I., (2007). 'Infectious canine hepatitis'. (C) Copyright 1997-2012 foster and smith, Inc., All Rights Reserved. Downloaded from www.peteducation.com/article.cfm?c=2+1556\&aid=405.

- Gerhold, R.W., Allison, A.B., Temple, D.L., Chamberlain, M.J., Strait, K.R., and Keel, M.K., (2007). 'Infectious canine hepatitis in a gray fox (Urocyon cinereoargenteus)'. J Wildl Dis, 43(4):734-6. 
- Gornall, A.G., Bardawill, C.J. and David, M.M., (1949). 'Determination of serum proteins by means of the biuret reaction'. $J$ Biol Chem, 177 (2):751-766.

- Green, E.C. (1998). 'Infectious canine hepatitis and canine acidophil cell hepatitis'. Infectious disease of dog and cat (2nd E.d.).22-28.

- Greene, C.E., (1990). 'Infectious Canine Hepatitis'. In: Greene, C.E. (Ed.), Infectious Diseases of the Dog and Cat. WB Saunders, Philadelphia, 242-251.

- Higuchi, R., (1990). 'Recombinant PCR. In : PCR protocols .A Guide to Methods and Applications (MA Innis, DH Gelfand, JJ Sninsky, TJ White, eds ), Academic Press.san Diego, CA.177-183.

- Hoskins, J.D., Ettinger, S.J., and Feldman, E.C., (2000). 'Textbook of Veterinary Internal Medicine'. W.B. Saunders Co. Philadelphia. 418-419.

- Hu, R.L., Huang, G., Qiu, W., Zhong, Z.H., Xia, X.Z. and Yin, Z., (2001). 'Detection and differentiation of CAV-1 and CAV-2 by polymerase chain reaction'. Vet Res Commun, 25 (1):77-84.

- Kapsenberg, J.G., (1959). 'Relationship of infectious canine hepatitis virus to human adenovirus'. Proc Soc Exp Biol Med, 101:611-614.

- Kasem, S., Yu, M.H., Yamada, S., Kodaira, A., Matsumura, T., Tsujimura, K., Madbouly, H., Yamaguchi, T., Ohya, K. and Fukushi, H., (2010). 'The ORF37 (UL24) is a neuropathogenicity determinant of equine herpesvirus 1 (EHV-1) in the mouse encephalitis model'. Virology, 400 (2):259-270. 
- Khodeir, M.H., El-Gallad, S.m., Edries, S.M., Amani, A., Saleh and Daoud, A.M., (2003-I). 'studies on canine hepatitis in Egypt. IIsolation of the local strain and its propagation in cell cultures'.3rd Int. Sci. Conf., Mansoura, 295-316.

- lee, Mary (2009). 'Basic Skillsin Interpreting Laboratory Data'. ASHP.259.

- Linne, T., (1992). 'Differences in the E3 regions of the canine adenovirus type I and type II'. Virus Research, (23):119-133.

- Martin, R.C, and B.N. Ames., (1961). 'A method for determining the sedimentation behavior of enzymes: application to protein mixtures'. J. Bicl. Chem. 236:1372-1379.

- Mengel, Mark, B., Schwiebert, L., Peter, (2005). 'Family medicine: ambulatory care\& prevention'. McGraw-Hill Professional. 268

- Moulton, J.E. and Frazier, L.M., (1961). 'Deoxyribonucleic acid and protein changes in dog kidney cells infected with infectious canine hepatitis virus'. Virology, 15:91-101.

- Muller, C., Sieber-Ruckstuhl, N., Decaro, N., Keller, S., Quante, S., Tschuor, F., Wenger, M. and Reusch, C., (2010). 'Infectious canine hepatitis in 4 dogs in Switzerland'. Schweiz Arch Tierheilkd, 152 (2):63-68.

- Nyblom, H., Berggren, U., Balldin, J., Olsson, R., (2004). 'High AST/ALT ratio may indicate advanced alcoholic liver disease rather than heavy drinking'. 
- Nyblom, H., Bjornsson, E., Simren, M., Aldenborg, F., Almer, S., Olsson, R., (2006). ' The AST/ALT ratio as an indicator of cirrhosis in patients with PBC'.

- Pratelli, A., Martella, V., Elia, G., Tempesta, M., Guarda, F., Capucchio, M.T., Carmichael, L.E. and Buonavoglia, C., (2001). 'Severe enteric disease in an animal shelter associated with dual infections by canine adenovirus type 1 and canine coronavirus'. $J$ Vet Med B Infect Dis Vet Public Health, 48 (5):385-392.

- Rubarth, S., (1947). 'An acute virus disease with liver lesion in dogs (hepatitis contagiosa canis) A pathologico-anatomical and etiological investigation'. Acta Path. Microbiol. Scand., Suppl. 69:9.

- Ruben, D., (2011). 'Understanding Blood Work: The Complete Blood Count (CBC) for Dogs'. Pet Place.Com. The Web's source of pet Information. (C) Copyright 1999-2011 Intelligent Content Corp., All Rights Reserved.

- Sambrook, J., and D.W., Russell, (2001). 'Molecular cloning'. A laboratory manual, 3rd edition.

- Sharp, M., and Dohme, C., (2011). 'Infectious Canine Hepatitis. Introduction'. A subsidiary of Merck Sharp \& Dohme Corp., Inc.Whitehouse Station, NJ USA. All Rights Reserved. Disclaimer / Feedback

- Szasz, G., (1969). 'A kinetic photometric method for serum gammaglutamyl transpeptidase'. Clin Chem, 15 (2):124-136. 
- Thompson, H., O'Keeffe, A.M., Lewis, J.C., Stocker, L.R., Laurenson, M.K. and Philbey, A.W., (2010). 'Infectious canine hepatitis in red foxes (Vulpes vulpes) in the United Kingdom'. Vet Rec, 166 (4):111-114.

- Thornburg, L.P., (2000). 'A perspective on copper and liver disease in the dog'. J Vet Diagn Invest, 12 (2):101-110.

- Thornburg, L.P., (1998). 'Histomorphological and immunohistochemical studies of chronic active hepatitis in Doberman Pinschers'. Vet Pathol, 35 (5):380-385.

- Wang, J.X., Zheng, L., Song, S.X., Zhang, X., Li, L.M., Wang, F., Liu, Y.F. and Sun, S.H., (2007). 'Augmented humoral and cellular immune responses induced by canine adenovirus type 1 DNA vaccine in BALB/c mice'. Viral Immunol, 20 (3):461-468.

- Wigton, D. H., Kociba, G. J., and Hoover, E. A., (1976). 'Infectious canine hepatitis, animal model for viral-induced disseminated intravascular coagulation'. Blood. 47(2):287-96.

- Yasumura, Y. and Kawatika, Y., (1963). 'Studies on SV-40 virus in tissue culture'. Nihon Rinsho, 21: 1201-1215. 
الدلالات الكيميائية الحيوية التشخيصية للإلتهاب الكبدي المعدي في صغار الكلاب المصابة تجريبيا

إن الإتهاب الكبدي المعدي في الكلاب هو من أمراض الكانديدا واليوريديا الجهازية التي يسببها أدينوفيروس الكلاب من النوع الأول مسببا النزيف الكبدي الحاد , ويكون أنثد في صغار الكلاب عن

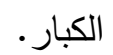

واستهدفت هذه الدراسـة التعرف علي أهم التغيرات الظاهريـة وتم التشخيص عن طريق تفاعل البلمـرة المنسلسل وكذلك التغيرات في اختبـارات وظائف الكبد والكلي والهيماتولوجيـة بالإضـافة علي التغيرات الهسنوبانولوجية.

قد أجريت هذه الدراسـه علي أربعه عشر كلب في أعمار تتراوح من ثلاثة إلي أربعة أثهر , أصحاء, خالية من جميع الطفيليات الداخلية والخارجية. تم خضوعهم لنظام غذائي منوازن مضافا اليه كميات كافيه من المياه في ظروف صحية, وقد وضعت في بيوت خاصة معزولة وصحية , ولم يتم تطعيم الحيوانات , ولقد وجدت خالية من الأجسام المضادة لمرض الإلتهاب الكبدي المعدي في الكلاب وتم فحصها من خلال إختبار المصل المتعادل للأجسام المضادة.

تم تقسيم الكلاب إلي مجموعتين الأولي تكونت من إحدي عشر كلبا وتم حقنها بفيروس الإلتهاب الكبدي المعدي للكلاب بينما المجموعة الثانية تكونت من ثلاثة كلاب ولم تعامل بأية معاملات وإعتبرت كمجموعة ضابطة غير مصابة.

وقد أظهرت النتيجة تحقيق ثماني عينات نتيجة عند حجم غليان bp 508 في الأسبوع الأول والثاني بعد العدوي, وإرتفاع إنزيمات الكبد مثل إنزيم ألانين امينو ترانسفيراز , وإنزيم أسبرتات امينو 
ترانسفيراز , وإنزيم الفوسفاتاز القاعدي , وإنزيم جاما جلوتاميل ترانسفيراز في الكلاب المصابة طوال فترة التجربة, في حين حدث انخفاض في مستويات البروتين الكلي , الألبيومين والجلوبيولين في الأسبوع الثالث والرابـع بعد العدوي, وبخصـوص صـورة الـدم في الكـلاب المصـابة أظهرت النتائج إنخفاض الهيمجلوبين, كرات الدم الحمراء, الصفائح الدموية والهيماتوكريت طوال فترة التجربة مدا أدي إلي فقر الدم. كما أظهرت النتائج إنخفاض عدد كريات الدم البيضاء في الكلاب المصابة طوال فترة التجربة في حين أن النيتروفيل زادت في الأسبوع الأول بعد العدوي ثم إنخفضت إلي المعدل الطبيعي في الأسبوع

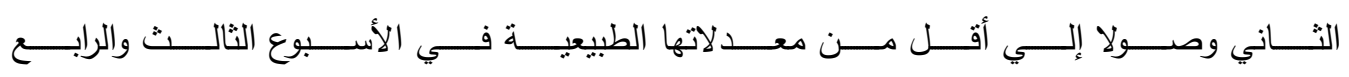
بعد العدوي.

وأظهرت النتائج أيضا إنخفاض معدلات الليمفوسايت في الأسبوع الأول بعد العدوي الفيروسية ثم

إزدادت في الأسبوع الثالث والرابع بعد العدوي الفيروسية. علاوة علي ذلك, زيادة معدلات الإيزونوفيل والمونوسايت تدريجيا طوال فترة التجربة, وأظهر تشريح أنسجة الكبد من الكلاب المصابة أثنكال إلتهاب الكبد.

وقد تلاحظ بشكل واضح في هذا الدراسة أن أكثر المؤشرات الحيوية التشخيصية سرعة وسهولة وحساسية في تنـخيص مـرض الإلتهاب المعدي في الكلاب في الحـالات الحسادة هو تفاعل البلمرة المنسلسل, بينما إختبارات وظائف الكبد وصورة الدم هي الأفضل في الحالات المزمنة. 